\title{
THE HOT-CARGO CLAUSE
}

\author{
RICHARD H. BATLETT*
}

The author offers a comparative examination of the use and legal operation of hot-cargo clauses in collective agreements in Canada and the United States. He examines the function and use of such clauses to evade legislative and common law restrictions on the conduct of a partial boycott during the term of a collective agreement. A review is also made of leading Canadian and American decisions concerning the validity of such clauses, and relevant provincial and American labor legislation. In conclusion, the author questions whether the public interest is served by such private agreements which permit the proliferation of the ambit of a labor dispute.

\section{FUNCTION AND USE}

"An agreement between a union and a unionized employer that his employees shall not be required to work on or handle 'hot goods' or 'hot cargo' being manufactured or transferred by another employer with whom the union has a labour dispute or whom the union considers and labels as being unfair to organized labour".. The reference in the United States legislation includes all forms of agreement whereby a union requires that the employer cease doing business with another employer: ${ }^{2}$

... contract or agreements, express or implied, whereby ... employer ceases or refrains or agrees to cease or refrain from handling, using, selling, transporting or otherwise dealing in any of the products of any other employer, or to cease doing business with any other persons.

Important instances of the hot-cargo clause are the picket line clause, which seeks to protect the right of employees to refuse to cross picket lines, the "struck goods" clause, the purpose of which is to prevent employees being required to handle "struck goods" and thereby support an employer in a labour dispute, and the subcontracting clause, which may seek to limit the contracting out of work which otherwise would be performed by the employees the union represents, or, to protect the wage scale and other conditions of work of those employees, or, to require the employer to deal only with unionized firms. ${ }^{3}$

American practice reveals the most extensive use of the clause, particularly in the construction and trucking industries. ${ }^{4}$ Hot-cargo clauses were employed in an endeavour to elude the secondary boycott proscription imposed by the 1947 Labor-Management Relations Act. ${ }^{5}$ The consequent exploitation of the hot-cargo clause in the United States led to the enactment of regulatory legislation in $1959 .{ }^{6}$ In Canada ${ }^{6}$ evidence of

-Assistant Professor of Law, University of Saskatchewan.

1 Final Report for the Select Committee on Improper Activities in the Labor or Management Field, S. Rep. No. 1189, 86th Cong., 2d. Sess. 3 (1960), at 3.

* Section $4(\cdot(\cdot)$ National Jabor Relations Act, 28 U.S.C. s. 151.

"Sce data and illustrations in P. A. Brinker, "Hot Cargo Cases since 1958," [1971] Lab. L. J. 586.

- Id. P. A. Brinker \& B. J. Taylor, "Secondary Boycott Analysis by Industry." [1973] Lab. L. J. 671.

5 Pub. L. No. 101, 80th Cong., 18t Sess. (1947); 29 U.S.C. 8. 151-168.

- Pub. L. No. 257, 86th Cong., 1st Sess. (1959); 29 U.S.C. s. 151-168.

6a It has been suggested that a hot-cargo clause may be implied into a contract of employment. In Stratford $v$. Lindley [1965] A.C. 269 it was advanced before the House of Lords by the respondent's counsel that the common law "right to strike [implied in the contract of employment] carries with it also the right to make a partial strike by imposing an embargo on the goods of a particular person or group of persons." See $K$. W. 
the use of such clauses is limited. In 1966 a survey of manufacturing industry did reveal that nine collective agreements covering 21,260 employees, nearly $10 \%$ of those covered by the survey, did include hotcargo clauses. ${ }^{7}$ And in a survey of collective bargaining agreements in British Columbia in 1970 it was discovered that $25 \%$ of the selected agreements contained a hot-cargo clause. ${ }^{8}$ Such indications as are available suggest the greater use of this form of clause in Canada in the future. The Teamsters Union seem intent to employ the tactics that were so successful in the United States, until curtailed by legislation, in Canada. In February 1971 eighty percent of the trucking industry in British Columbia was involved in a strike-lockout, the sole issue in dispute being the Teamsters' demand for a "struck goods" clause in a proposed new contract. ${ }^{9}$

The protection conferred by a hot-cargo clause consists in the provision thereby made in a collective agreement for the exercise of a partial labour boycott whenever the designated circumstances arise. A hot-cargo clause is drafted so as to evade the restrictions of labour relations legislation and the common law upon the conduct of such a boycott; in particular, to exclude work upon hot cargo from the obligations of the employees under the collective agreement. In order to understand the potential of a hotcargo clause the restriction upon a partial labour boycott which it seeks to evade must first be examined. In such an examination the problem posed by hot-cargo clauses is clear. To what extent should a union and an employer be free to contract so as to permit conduct otherwise prohibited by statute or the common law?

\section{THE PARTIAL LABOUR BOYCOTT}

\section{$A$. Character and Interests of the Parties}

The expression "partial boycott" is used to refer to a limited withdrawal of labour by an employee from his employer. It consists of a refusal to work in circumstances which are not exhaustive of those that arise in the service of the employer. These circumstances are likely to be delineated by the nature of the location where, the work upon which, and, the workers with whom, the employee is required to work. The ambit of the sanction is confined to the circumstances that provoked its exercise.

The major forms of the partial boycott are the "refusal to handle"

\footnotetext{
Wedderburn, Evidence to Royal Commission on Trade Unions, (H.M.S.O. 1966 Day 31. para. 56). Their Lordships did not consider the proposition and appeared not to favour it.

Consideration was afforded the argument by Hinkson J. in MacMillan Bloedel v. I.W.A. Local 1-357 (1970) 74 W.W.R. 745, 750-751 (B.C.S.C.). "It was submitted that there had been no strike. Upon the basis it was an implied condition of the contract of employment that the employees who were members of the I.W.A. would not handle products declared "hot" during the course of a lawful strike, it was contended that the actions of the boom men did not amount to a strike. There is no evidence before me upon which I could find any such implied condition. Rather it appears to me the plaintiff has established a strong prima facie case that the boom men have struck within the definition contained in the Labour Relations Act and the Mediation Commission Act, so that by exerting pressure on the plaintiff, they can in turn compel it to exert pressure on employers with whom the Guild is on strike to agree to terms or conditions of employment sought by the Guild. In my view, and having regard to the decision in Flanders Installations Lid. v. Int. Woodworkers of Amer. Local 1405 (1968) 62 W.W.R. 434, 66 D.L.R. (2d) at 441, reversing (1968) 62 W.W.R. 302, 66 D.L.R. (2d) 438. (B.C.C.A.) the plaintiff has made out a strong prima facie case that the 1.W.A. is in breach of its collective agreement and should be enjoined from continuing to be so in breach: Int. Brotherhood of Elec. Whrs. Local Union 2085 v. Winnipeg Bldrs.' Exchange (1967) 61 W.W.R. 682, (1967] SCR 628, 65 D.L.R. (2d) 242, affirming (1967) 61 W.W.R. 5i35, 57 D.L.R. (2d) 141."

: 1967 Labour Gazette p. 568.

" Survey of Collective Bargaining Agreements in British Columbia, (B.C. Dept. of Labour, Victoria, B.C., 1970) 30.
}

" Edmonton Journal. 20th February 1971, 27th February 1971. 
and the "refusal to cross a picket line." Reasons for a "refusal to handle" have been tabulated in order of occurrence, as:10

... protesting non-union goods .. ;

protesting prefabricated or other labor saving devices ...;

jurisdictional disputes ... ;

disputes over renewal of a contract .. ;

and enforcement of a contract....

The reluctance of employees to cross a picket line has been judicially recognized upon several occasions. ${ }^{11}$ Such reluctance arises from worker solidarity-the notion that directly or indirectly the economic interest of every worker is involved in the observance of all picket lines.

The narrow ambit of the sanction enables a readier resolution of the conflict of the interests of labour and management than in the circumstances of a total boycott. The employer is only subject to a partial withdrawal of its labour, which may preclude it from rendering assistance to the disputing employer but may not prevent it from carrying on business. The employees continue working except in circumstances where it is considered that such work would assist the disputing employer or be inimical to their own interests. The sanction may render positive aid to the disputing employees. The pressure imposed upon a disputing employer by means of a partial boycott of a nondisputing employer may not be significantly less than that imposed by a total boycott.

As with the private interests, the public interests may be more readily accommodated in the circumstances of the partial boycott. The public interest in free collective bargaining demands the freedom to exercise such economic pressure as is available to labour and management. The partial boycott enables labour to exert such pressure upon the disputing employer. The public interest in commercial and industrial peace is served insofar as unrest is less severe than in the circumstances of a total boycott. Moreover the narrow ambit of labour disputes imposed in the service of the latter interest may necessitate the use of the partial boycott to correct the ensuing imbalance of bargaining power.

A different analysis of the partial boycott was delivered by Sir John Donaldson, President of the now defunct British National Industrial Relations Court in Heaton's Transport (St. Helens) Ltd. v. Transport and General Workers Union:12

'Blacking' damages the public, fellow workers and the employers of those fellow workers. It does not damage those who do the 'blackings'. They draw their pay. It is an unfair weapon....

\section{B. Prohibition}

\section{Restraints imposed during term of Collective Agreement}

Restraints during the term of the collective agreement in the United States and Saskatchewan are governed by the nature of the clauses voluntarily agreed upon. In the remaining Canadian jurisdictions, legislation prohibits industrial action during the term of a collective agreement

16 P. A. Brinker, "Secondary Strikes and Picketing," [1972], Lab. L. J. 681, 681-682. Article discusses incidence and types of secondary labour boycott in the United States.

$"$ Smith Bros. Construction v. Jones, (1953) 4 D.L.R. (2d) 255, 264 (Ont. H.C.) per McLennan, J.

Also: L. A. Young Spring \& Wire Corp. 70 NLRB 868, 874 (1946) enforcement denied. 163 F.2d. 905 (D.C. Circ. 1947), cert., denied, 333 U.S. 837 (1948), where the Board observed that it "is almost a rule of trade union ethics for one labor union to respect a picket line established by another."

12 [1973] I.C. 23 at 32 (NIRC). The Court was abolished by the Trade Union and Labour Relations Act, 1974. 
irrespective of the terms agreed between the parties. The enjoinder is accomplished by the proscription of "strikes" during the term of the collective agreement. ${ }^{13}$ The ambit of each definition of "strike" determines the extent to which the partial boycott is restrained. The traditional legislative definition is that stipulated in the statutes of Alberta, ${ }^{14}$ British Columbia ${ }^{15}$ and Newfoundland:16

'strike' includes a cessation of work, or refusal to work or to continue to work, by employees, in combination or in concert or in accordance with a common understanding.

In the other Canadian jurisdictions the term "strike" is more broadly defined. ${ }^{17}$ The only reported case on the problem of interpretation is $\mathrm{Kel}$ ly, Douglas \& Co. Ltd. v. Bakery \& Confectionary Workers' Int. Union of America, Local 468, ${ }^{18}$ decided in British Columbia.

Union members in two shops of a company refused, on instructions from the union, to deliver essential materials to non-union shops of the same company. The employer was granted an injunction on the grounds that the refusal amounted to an unlawful strike. Collins J. commented: ${ }^{19}$

Although this is not a refusal to do any baker work at all, nevertheless it is a refusal in accordance with a common understanding among them to work for the purpose of compelling their employer to agree to terms or conditions of employment for certain employees at ... [the other stores]. It is my view that this refusal constitutes a strike within the definition of that term ....

This decision is supported by the several reported cases involving a refusal to do overtime. ${ }^{20}$ In these cases, as in Kelly, Douglas \& Co. Ltd.,21 the court has had to decide whether the undertakings refused constituted "work" within the meaning of the statutory expression "refusal to work." In each case it has been held that the overtime, even in the absence of an express obligation on the employees, comprised a portion of the

13 8. 180(1) Canada Labour Code R.S.C. 1970 c. L-1, as amended by S.C. 1972 c. 18; s. 125 Alberta Labour Act SA. 1973, c. 33; a. 79, Labour Code of British Columbia S.B.C. c. 122; s. 77(2) Labour Relations Act (Manitoba) S.M. 1972 c. 75; 8. 92(1) Industrial Relations Act S.N.B. 1971 c. 9; 8. 2311) Labour Relations Act R.S.N. 1952 c. 258; 8. 46 Trade Union Act S.N.S. 1972 c. 19; 8. 63(1) Labour Relations Act R.S.O. 1970 c. 232; 8. 39 Prince Edward lsland Labour Act S.P.E.I. 1971 c. 35; 8. 95 Labour Code R.S.Q. 1964 c. 141.

8. 36 Labour Relations Act R.S.O. 1970 c. 232 and s. 35 Prince Edward Island Labour Act S.P.E.I. 1971 c. 35 also provide:

Every collective agreement shall provide that there will be no strikes or lockouts so long ts the agreement continues to operate.

11 8. 49(1)(1) Alberta Labour Act S.A. 1973 c. 33.

15 8. 1(1) Labour Code of British Columbia S.B.C. 1973 c. 122.

16 8. 2(1)(p) Labour Relations Act R.S.N. 1952 c. 258.

17 e.g.: 8. 1(v) Labour Relations Act (Manitoba) S.M. 1972 c. 75:

"Strike" includes

(i) a cessation of work, or

(ii) a refusal to work, or

(iii) a refusal to work or continue to work, or

(iv) a refusal to continue the standard cycle or normal pattern of operation in a place of employment, or

(v) a slow down of work, or

(vi) an activity in relation to their work that is designated to restrict or limit output.

by or on the part of employees in combination or in concert or in accordance with a common understanding for the purpose of compelling their employer to agree to terms or conditions of empluyment or to aid other employees in compelling the employer of those other employees to agree to terms or conditions of employ. ment, and "to strike" has a corresponding meaning; ..

Also: 8. 107(1) Canada Labour Code R.S.C. 1970 c. L-1 as amended S.C. 1972 c. 18; s. 2(1)(cc) Industrial Relations Act S.N.B. 1971 c. 9; s. 1(1)(v) Trade Union Act S.N.S. 1972 c. 19; 8. 1(m) Labour Relations Act R.S.O. 1970 c. $232 ;$ 8. $7(1 \times k)$ Prince Edward Island Labour Act S.P.E.I. 1971 c. 35.

is (1965) 48 D.L.R. 520; 65 C.L.L.C. $[14,072] 11,323$ (B.C.S.C.).

10 Id. at 11,330 .

30 See: Re Marine Workers, Local No. 1 and Labour Relations Board of British Columbia (1951) 4 W.W.R. 529 [1952] 2 D.L.R 63 (B.C.S.C.) Ontario Hydro Employees, Local 1000 C.U.P.E. v. Hydro Electric Power Commission of Ontario, 70 C.L.L.C. $\{16,007\} 16,028$, (O.L.R.B.), affirmed 70 C.L.L.C. [14,031] 14,271, (Ont. C.A.).

21 (1965) 48 D.L.R. 520; 65 C.L.L.C. $\{14,072\} 11.323$ (B.C.S.C.). 
"work." Having made this finding the courts have shown no reluctance in concluding that such a partial boycott lay within the expression "refusal to work."

\section{Specific statutory regulation of the partial labour boycott}

Recent legislation in Alberta and Saskatchewan has been enacted specifically directed to the proscription of certain forms of partial boycott.22 The impetus for such legislation appears to be a desire to preclude the "contracting out" of such boycotts from prohibition by means of hot-cargo clauses and a notion that certain forms of partial boycott are so pernicious as to require special legislation.

In 1969 the legislature of Saskatchewan amended the Trade Union Act of the province by the addition of section 9(5). The section stated:

It shall be an unfair labour practice for a trade union or an employee or a group of employees for any reason whatsoever to refuse to take delivery of goods from a carrier or to refuse to assist in the loading of a carrier of goods for shipment unless the board is satisfied that the union or the employee or group of employees has a valid trade dispute.

The section was repealed in $1972 .{ }^{23}$ In 1960 and 1970 the Alberta Legislature enacted what is now section 156 of the Alberta Labour Act.

No employee shall

(a) refuse to perform work for his employer for the reason that other work was or will be performed or was not or will not be performed by any person or class of persons who were or are not members of a trade union or a particular trade union, and

(b) refuse to take delivery of goods from a carrier or refuse to assist in the loading of a carrier of goods for shipment except where the carrier and his employees are engaged in a strike or lockout permitted by this Part.

Section 156(a) bans partial labour boycotts in jurisdictional disputes and those directed against non-union labour. Section $156(\mathrm{~b})$ bans refusals to handle goods to or from a carrier except where the latter's employees are lawfully on strike. Subsection (b) seeks to preclude the exercise of the refusal to handle where it is most effective; e.g. at points of dispatch and delivery.

The use of the phrase "for any reason whatsoever" in the Saskatchewan legislation effectively eliminated any suggestion that the application of the provision might be excluded by contract. The Alberta provision has no such expression. The provision employs similar language to that used in those sections that limit strike action. The prohibition might thus be evaded by the exclusion from the employees' contractual obligations to the employer of the work refused.

Contrary positions to those evidenced in Alberta and Saskatchewan have been legislated in Manitoba and the United States. In the United States the National Labour Relations Board maintains that refusals to cross picket lines are protected by section 7 of the National Labour

\footnotetext{
22 It has been maintained that the "slowdown" proscription embodied in section 4(2) Labour Code of British Columbia extended to a refusal to handle. $8.4(2)$ :

No trade union and no person acting on behalf of a trade union and no employee shall support, encourage, condone, or engage in any activity that is intended to or does restrict or limit production or services. The Labour Relations Board of British Columbia has issued orders to a union to "cease and rectify" by ad. vising its members not to refuse to load or discharge oil from vehicles operated by trucking companies that were involved in a labour dispute with their employees. B.C. Dept. of Labour Weekly Summary of Activities: Imperial Oil Enterprises Ltd., (Vancouver) and Oil, Chemical and Atomic Workers Local 9.601, Vol. 12, 43, Oct. 22, 1965. Shell Oil Co., (Vancouver) and Oil, Chemical and Atomic Workers Local 9-601, Vol. 12,45, Nov. 5, 1965.

Such a notion was rejected by Verchere J. in C.P.R. and Building and Truck Drivers Union, Local 213 [1971] 5 W.W.R. 1, 45 (B.C.S.C.).

2. s. 43 Trade Union Act S.S. 1972 c. 137.
} 
Relations Act" which guarantees workers the right to "engage in ... concerted activities for . . mutual aid or protection." It is an unfair labour practice to interfere with such right by, for example, dismissal on account of such conduct. In Manitoba 8. 12(1) of the Labour Relations Act provides:

An employee who is in a unit of employees of an employer in respect of which there is a collective agreement in force and who refuses to perform work which would directly facilitate the operation or business of another employer whose employees within Canada are lawfully on strike or locked out is not, by reason of that refusal, in breach of the collective agreement or of any term of condition of his employment and is not, by reason of that refusal, subject to any disciplinary action by the employer or the bargaining agent that is a party to the collective agreement.

s. 13(1) provides:

No employer and no person acting on behalf of an employer shall discharge or refuse to continue to employ or refuse to re-employ or lay-off or transfer or suspend or alter the status of an employee who has refused to perform all or any of the duties or responsibilities of an employee who is participating in a legal strike or lockout.

The sections enable an employee to refuse to aid a struck employer in the conduct of a dispute. The protection conferred by section 12(1) extends to the denial of a breach of the collective agreement by the designated contract. The section may obviate tortious liability upon the inducement of such conduct in a similar manner to a hot-cargo clause.

\section{The Inducement of a Partial Labour Boycott}

\section{(a) Common Law}

Inducement to industrial action in Canada is regulated at common law by a complex of the torts of interference with existing contractual relations, intermediation, unlawful interference with trade and conspiracy. The inducement of a partial labour boycott, such as a refusal to handle, may result in the breach of a collective agreement, or the breach of a commercial contract to which the employer is a party. Liability may then attach upon such satisfaction of the required unlawful element in these torts.

An instance of such liability is Interprovincial Steel and Pipe Corp. Ltd. v. Lorne MacDonald. ${ }^{25}$ Pipe mill employees engaged in a legal strike at the plaintiff's plant and established picket lines at the plant entrances, including the north entrance which was reserved for Steel Mill employees and construction workers thereat engaged. The steel mill employees and construction workers refused to cross the picket line. The Steel Mill employees' collective agreement was "still in full force and effect."

Disbery J., in Chambers, enjoined the defendants "from interfering in the performance of the Contracts or Agreements between the Plaintiff and the United Steelworkers of America, Local 5890, and between the Plaintiff and other persons or corporations relating to the construction of a certain new Melt Shop in connection with the Plaintiff's Steel Mill," and, from picketing the north entrance. The Order did not extend to "lawful picketing at other entrances."

2428 U.S.C. 8. 157

Redwing Carriers Inc. 137 NLRB 1545 (1962) enforced sub nom. Teamsters, Local 79 v. NLRB 325 F.2d. 1011 (D.C. Circ.-1963), cert. denied 377 U.S. 905 (1964).

25 (Sask. Q.B.) June 20, 1972 unreported. Details of the case and decision were made available by D. K. MacPherson Q.C. of MacPherson, Leslie \& Tyeman of Regina, Saskatchewan, who acted for the plaintiff. Also: Bennett \& White Alberta Ltd. v. Von Reeder \& I.U.O.E., Local 933, (1957) 6 D.L.R. (2d) 326 (Alta. C.A.). 
Liability may attach upon interference with a commercial contract irrespective of the absence of a breach of a collective agreement. In MacMillan Bloedel (Saskatchewan) Ltd. v. Powell ${ }^{26}$ a legal strike occurred at a plant while construction to enlarge its capacity was in progress. Picketing ensued, resulting in a picket line being placed across both the main plant entrance and another especially reserved for use by the construction workers, who were employed by outside contractors and suppliers. The construction workers refused to cross the picket line, thereby bringing the construction program to a halt. Sirois J., in the Saskatchewan Court of Queen's Bench continued the injunction restraining picketing at or near the construction entrance. The learned judge found that the plaintiff had contracts with outside suppliers and contractors of which the defendants were aware and of which they attempted to induce a breach. The picketing was thus a "besetting" of the plaintiff's premises and unlawful.

The doctrine of conspiracy to injure was described by Lord Simon in Crofter Hand Woven Harris Tweed v. Veitch. ${ }^{27}$

Liability must depend on ascertaining the predominant purpose. If that predominant purpose is to damage another person and damage results that is tortious conspiracy. If the predominant purpose is the lawful protection or promotion of any lawful interests of the combiners (no illegal means being employed) it is not a tortious conspiracy even though it causes damage to another person.

The determination of "predominant purpose" in conspiracy to injure provoked Professor Carrothers to remark: ${ }^{28}$

The real issue is whether at our present stage of social and economic development it can be said that the union has a legitimate interest vis-a-vis the person injured by the picketing.

The Canadian judiciary are apparently not prepared to recognize the legitimate character of picketing directed to the inducement of a secondary ${ }^{29}$ labour boycott such as a refusal to handle or refusal to cross a picket line. McRuer C.J.H.C., commented in General Dry Batteries v. Brigenshaw: ${ }^{30}$

I am not at all convinced that, in what one may call the guise of advancing their interest in a labour dispute, employees are entitled to bring external pressure to bear on others who are doing business with a particular person for the purpose of injuring the business of their employer so that he may capitulate in the dispute. It is one thing to exercise all the lawful rights to strike and the lawful rights to picket; that is a freedom that should be preserved and its preservation has advanced the interests of the labouring man and the community as a whole to an untold degree over the last half century. But it is another thing to recognize a conspiracy to injure 80 that benefits to any particular person or class may be realized.

The dictum of McRuer C.J.H.C., was cited in Wilson Court Apartments v. Genovese. ${ }^{31}$ The case concerned common-situs picketing at a construction site. The preparedness of the Chief Justice to deny justification in such circumstances indicates a reluctance to deviate from that regime of liability imposed by the tort of interference with existing contractual

\footnotetext{
2669 C.L.L.C. $[14,174] 714$ (Sask. Q.B.). Also: Smith Bros. Construction v. Jones (1953) 4 D.L.R. (2d) 255 (Ont. H.C.).

27 [1942] A.C. 435 at 445.

2n A.W.R. Carrothers, Collective Bargaining Law in Canada (Toronto, Butterworths, 1965) 459.

29 The term "secondary" is here employed as a reference to a boycott of a "neutral" or "secondary" party to a labour dispute. "Primary" refers to a "non-neutral" party.

30 [1951] 4 D.L.R. (2d) 414 at 419.20 (Ont. H.C.).

31 (1958) 14 D.L.R. (2d) 768, 761 per McRuer, C.J.H.C. (Ont. H.C.).
} 
relations. In Britain, the notion of justification in conspiracy to injure has been utilized in the maintenance of a consistent balance of interests between labour and management. In Crofter Hand Woven Harris Tweed v. Veitch ${ }^{32}$ a refusal to handle was considered justified.

The Ontario Court of Appeal in Hersees v. Goldstein ${ }^{33}$ declared secondary picketing "illegal per se." The decision permits the circumvention of the requirements of conventional tort analysis. The character of the picketing is determined by the location at which it takes place rather than the injuries to contractual rights occasioned thereby.

(b) Statute

\section{(i) United States}

Section 8(b)(4)(i) of the National Labor Relations Act states:

It shall be an unfair labor practice for a labor organization or its agents-

... to engage in, or to induce or encourage any individual employed by any person engaged in commerce or in an industry affecting commerce to engage in a strike or $a$ refusal in the course of his employment to use, manufacture, process, transport, or otherwise handle or to perform any services ... where ... an object thereof is .... (b) forcing or requiring any person to cease using, selling, handling, transporting, or otherwise dealing in the products of any other producer, processor, or manufacturer, or to cease doing business with any other person ... Provided, that nothing contained in this clause (b) shall be construed to make unlawful, where not otherwise unlawful, any primary strike or primary picketing.

Picketing at the location of a primary or secondary employer may be interpreted as inducing or encouraging an employee to engage in a strike or refusal to handle with the object of compelling a person to cease doing business with any other person. The ambit of the statutory proscription is restricted by the proviso to section $8(\mathrm{~b})(4)(\mathrm{B})$. Referring to the proviso, the House Conference Report states: ${ }^{34}$

The purpose of this provision is to make it clear that the changes in section $8(b)(4)$ do not overrule or qualify the present rules of law permitting picketing at the site of a primary labor dispute. This provision does not eliminate, restrict or modify the limitations on picketing at the site of a primary labor dispute that are in existing law.

The recognition accorded the appellations "primary," and by implication "secondary," provides for those circumstances in which a labour boycott of secondary employees is induced, but which inducement is regarded as protected or primary activity. ${ }^{35}$

A strike, by its very nature, inconveniences those who customarily do business with the struck employer. Moreover, any accompanying picketing of the employer's premises is necessarily designed to induce and encourage third persons to cease doing business with the picketed employer. It does not follow, however, that such picketing is therefore proscribed ....

\section{(ii) Alberta, British Columbia, New Brunswick and Newfoundland}

The legislation of Alberta, British Columbia, New Brunswick and Newfoundland proscribes persuading anyone not to: ${ }^{36}$

32 [1942] A.C. 435.

21 [1863] 2 O.R. 81; 63 C.L.L.C. [15,461] 666 (Ont. C.A.).

34 H. R. Rep. No. 1147, 86th Cong. 18t Sess. p. 38 (1959); Vol. 1 Legis. History of Labor-Management Reporting and Disclosure Act 1959, p. 442. Oil Workers Int. Union (Pure Oil CoJ 84 NLRB 315,318 (1969).

3s NLRB v. Denver Building and Construction Trades Council 341 U.S. 675, 71 S. Ct. 943 (1951).

* в. 156 Alberta Labour Act 1973 S.A. 1973 c. 33; 8. 101, 85 Labour Code of British Columbia S.B.C. 1973 c. 122; 8. 105 Industrial Relations Act S.N.B. 1971 c. 9; 8. 43A Labour Relations Act R.S.N. 1952 c. 258 as amended by S.N. 1963, No. 82. The Alberta legislation confines such perauasion to the place of employment of the lawfully striking employees. 
(a) enter an employer's place of business, operations or employment; or

(b) deal in or handle the products of any person; or

(c) do business with any person except at the employer's place of business, operations or employment during a lawful strike.

The language encompasses inducement of both a refusal to cross a picket line and a refusal to handle.

\section{VALIDITY OF THE HOT-CARGO CLAUSE}

\section{A. United States}

\section{Section 8(e) of the National Labor Relations Act provides:}

It shall be an unfair labor practice for any labor organization and any employer to enter into any contract or agreement, express or implied, whereby such employer ceases or refrains or agrees to cease or refrain from handling, using, selling, transporting or otherwise dealing in any of the products of any other employer, or to cease doing business with any other person, and any contract or agreement entered into hereafter containing such an agreement shall be to such extent unenforceable and void ....

The legislative history of section 8(e) disclosed the intention of Congress that it be limited in application to secondary activity. ${ }^{37} \mathrm{~A}$ disclaimer to the section explicitly protected the right of refusal to cross primary picket lines and the right to sign contracts immunizing such refusals from employer discipline, but was replaced on the floor of the House. The following broad and all-encompassing declaration of congressional policy was inserted into the Bill: ${ }^{38}$

Provided. That nothing contained in this clause (B) shall be construed to make unlawful, where not otherwise unlawful any primary strike or primary picketing.

The proviso has been interpreted by the judiciary as if applicable to section $8(e)$. Consequently the clauses that protect primary activity as opposed to secondary activity are not proscribed by section $8(e)$.

The International Brotherhood of Teamsters formerly employed a standard clause which provided that the union reserved the right to refuse to handle unfair goods, which were defined as goods destined to or from struck employers. Since the enactment of section 8(e) such clauses have been void. ${ }^{39}$ Not all struck work clauses are within the ambit of section 8(e). Those provisions concerned with enabling employees to refuse to engage in strike-breaking activities may be protected by the "ally" doctrine ${ }^{40} \mathrm{~A}$ clause permitting an employee to respect any and all picket lines violates the ban contained in section 8(e). It is "unlawful and violative of section $8(\mathrm{e})$ insofar as, and to the extent that, it applies to secondary activity." 41 The objective of work preservation may direct a sub-contracting clause. National Woodwork Manufacturer's Association v. $N L R B^{42}$ concerned a strike by carpenters, who, acting pursuant to a clause in their collective agreement, refused to hang pre-fitted doors.

\footnotetext{
37 National Woodwork Manufacturers Assoc. v. NLRB, 386 U.S. 612,638 per Brennan, J. (1967); 55 L.C. [11,842].

3e Truck Drivers, Local 413 v. NLRB, 334 F.2d. 539,542 (1964).

32 Staats Express 131 NLRB 242 enforced 298 F.2d. 105 (1961).

10 e.g.:

". . . the employees covered by this contract shall not be required to handle any lithographic work farmed out directly and indirectly by [the struck] employer, other than work which the employee customarily has performed for the employer involved in such strike or lockout."

employing Lithographers of Greater Miami 130 NLRB 968, 301 F.2d. 20 (1962).

The "ally" doctrine deprives certain entities of neutral status upon the demonstration of sufficient economic entanglement in a labour dispute.

1 Int. Bro. of Teamsters, Local 695 v. NLRB 53 L.C. [11,217] (CA.DC, 1966).

22386 U.S. 612 (1967); 55 L.C. $[11,842] 18,703$.
} 
Brennan J., delivering the judgment of the majority of the Supreme Court, stated:43

... The determination whether the 'will not handle' sentence of Rule 17 and its 'n. forcement violated s. $8(\mathrm{e})$ and 8 . $8(\mathrm{~b})(4)(\mathrm{B})$ cannot be made without an inquiry into whether, under all the surrounding circumstances, the Union's objective was preservation of work for F's employees, or whether the agreements and boycott were tactically calculated to satisfy union objectives elsewhere. Were the latter the case, F, the boycotting employer, would be a neutral bystander, and the agreement or boycott would, within the intent of Congress, become secondary. There need not be an actual dispute with the boycotted employer, here the door manufacturer, for the activity to fall within this category, so long as the tactical object of the agreement and its maintenance is that employer, or benefits to other than the boycotting employees or other employees of the primary employer thus making the agreement or boycott secondary in its aim. The touchstone is whether the agreement or its maintenance is addressed to the labor relations of the contracting employer vis-a-vis his own employees .... That the 'will not handle' provision was not an unfair labor practice in this case is clear. The finding of the Trial Examiner, adopted by the Board, was that the objective of the sentence was preservation of work traditionally performed by the job-site carpenters. This finding is supported by substantial evidence, and therefore the Union's making of the 'will not handle' agreement was not a violation of $8.8(\mathrm{e})$.

The decision of the Supreme Court endorsed the approach of the District of Columbia Court of Appeals in Orange Belt District Council of Painters No. 48 v. NLRB. ${ }^{44}$ Wright J., indicated that a subcontracting clause providing that only organized plants receive contracted-out work would be secondary, because it would reach beyond the immediate employer-employee relationship to promote the status of unions generally without protecting bargaining-unit jobs. But, he continued, a clause requiring that subcontracted employees be paid union wages and benefits without regard to union membership would be primary, since it would affect peripheral parties only to the extent necessary to protect bargaining-unit jobs by removing the employer's incentive to "farm out" work at lower wages. ${ }^{45}$

The test as to the 'primary' nature of a subcontractor clause in an agreement with a general contractor has been phrased by scholars as whether it 'will directly benefit employees covered thereby,'46 and 'seeks to protect the wages and job opportunities of the employees covered by the contract.' 17 We have phrased the test as whether the clauses are 'germane to the economic integrity of the principal work unit, 48 and seek 'to protect and preserve the work and standards [union] has bargained for, ${ }^{99}$ or instead 'extend beyond the [contracting] employer and are aimed really at the union's difference with another employer. ${ }^{150}$ As we said in Retail Clerks, the Board may not rely on

'blanket pronouncements in respect to subcontracting clauses. These clauses take many forms. Some prohibit subcontracting under any circumstances; some prohibit it unless there is sufficient work in the shop to keep shop employees busy; some prohibit it except where the subcontractor maintains a wage scale and working conditions commensurate with those of the employer who is party to the collective agreement. On the face of it, these provisions would seem to be legitimate

43 Id. at 18,715-18,716. Italics added.

4" 328 F.2d. 534 (D.C. Circ. 1964 ).

is Id. at 638, 539. Confirmed in Truck Drivers' Local 113 v. NLRB 334 F.2d. 539 (1964) Lewis v. NLRB 350 F.2d. 801 (D.C. Circ.1865).

46 Aaron, "The Labor-Management Reporting and Disclosure Act of 1959," (1960), 73 Harv. L. Rev. 1086, 1119.

47 "Landrum-Griffin Amendments to the National Labor Relations Act," 44 Minn. L. Rev. 257, 273 (1959).

40 District No. 9. International Ass'n of Machinists v. NLRB, 315 F.2d. 33, 36; 46 L.C. [17.908] 27.789 (D.C. Circ. 1962). We there condemned a provision as not within "the area of a legitimate union claim designed to limit the work to employers maintaining labor standards commensurate with those required by the Union ..." but rather constituting "concurrence between the union and (the contracting employer] to boycolt another employer for reasons not strictly germane to the economic integrity of the principal work unit."

49 Retail Clerks Union Local 770 v. NLRB, 296 F.2d. 368, 374, 43 L.C. 117.049] 24, 860 (D.C. Circ. 1961$)$.

so Local 636, United Association v. NLRB, 278 F.2d. 858, 864, 39 L.C. $[66,362] 69,852$ (I).C. Circ.-1960). 
attempts by the union to protect and preserve the work and standards it has bargained for. In the latter supposition, for example, the union may be attempting to remove the economic incentive for contracting out, and thus to preserve the work for the contracting employers.' 3 !

Exempted from the application of section 8(e) are agreements between unions and employers:

... in the construction industry relating to the contracting or subcontracting of work to be done at the site the construction, alteration, painting or repair of a building, structure or other work.

A similar exemption is extended to integrated production processes in the apparel and clothing industry. The exemptions are the product of the special importance of sub-contracting in those industries. A union is able to obtain some control over sub-contractors by means of a hot-cargo clause.

\section{B. Canada ${ }^{52}$}

Any agreement which tends to be injurious to the public or against the public good is void as being contrary to public policy. ${ }^{33}$

It is a general principle of the common law that a man is entitled to exercise any lawful trade or calling as and where he wills, and the law has always regarded jealously any interference with trade, even at the risk of interference with contract, as it is public policy to oppose all restraints upon individual liberty of individual action which are injurious to the interests of the state.

A hot-cargo clause is susceptible to challenge as a contract in restraint of trade and prima facie void. Such a contract can only become binding if it is reasonable in the interests of both parties and also in the interest of the public at large. ${ }^{54}$ The doctrine affords a flexible mechanism for the appraisal of private interests and their relation to the public interest. No precedential guide is, however, available in the application of the doctrine to hot-cargo clauses, and it is tempting to recite the caution of Lord Bramwell in Mogul S. S. Co. v. McGregor, Gow \& Co.55 The doctrine "should only be evoked in clear cases in which the harm to the public is substantially incontestable, and does not depend upon the idiosyncratic inferences of a few judicial minds." It might be suggested that labour legislation authorizing modern collective bargaining has removed such incidents of its practice as the hot-cargo clause from the doctrine's ambit. In the regime imposed by such legislation it would seem difficult to establish that "the harm to the public is substantially incontestable."

The proliferation of the hot-cargo clause in collective agreements in Canada has been most marked in British Columbia, and it is in the

s1 Retail Clerks Union Local 770 v. NLRB. 296 F.2d. 368, 373-374, 43 L.C. [17,049] 24,860 (D.C. Circ.-1961).

32 It has been suggested that a hot-cargo clause may be void under the Combines Investigation Act R.S.C. 1970 c. C-23, e.g., C.P.R. v. Truck Drivers, Local 213 [1971] 5 W.W.R. 1, 32, R.S.C. It is submitted that the suggestion is unfounded. B. 4 provides:

"Nothing in this Act shall be construed to apply to combinations of workmen or employees for their own reasonable protection as such workmen or employees."

Also see clause 89 Competition Bill-C.256

The conflict between the policies promoted by labour relations legislation and competition statutes euggeste that the determination of "reasonable protection" is likely to prove to be 80 complex a task as to dis. courage the invoking of the latter proscription except in the most extreme circumstances.

It has been declared in the United States Supreme Court in Allen Bradley v. Loc. Union No. 3 I.B.E.W. (1945) 325 U.S. 797, 9 [51,213] 51,652, 51,657 per Black. J. "Employers and the union did here make bargaining agreements in which the employers agreed not to buy goods manufactured by companies which did not employ the members of Local No. 3. We may assume that guch an agreement alone would not have violated the Sherman Act."

3s 38 Hala, (3d. Ed.) 15.

s4 Nordenfelt v. Maxim Nordenfelt Guns and Ammunition Co. [1894] A.C. 565.

ss [1892] A.C. 25, 45 (H.L.). 
courts of that province that the provision has been the subject of adjudication. The decisions are recent and contain limited judicial consideration of the subject. The judiciary seek to evade such analysis whenever it is not thought absolutely necessary..$^{56}$ Several decisions exhibit a desire to assume the validity of the hot-cargo clause. ${ }^{57}$

The Court of Appeal of British Columbia initiated doubts as to the validity of the hot-cargo clause in Doman's Transport v. Building and Truck Drivers' Union, Local 31.58 A clause in a collective agreement provided that in outside deliveries "preference shall be given to those firms having agreements with a Local of the Teamsters Union" and that additionally contracted trucks should be obtained only from firms organized by the Teamsters. The Court considered the submission that the clause was void or unlawful on grounds of public policy to be sufficiently substantial to establish a fair question as to the existence of the plaintiff's right and as to the commission of a wrong. An injunction was granted.

The leading decision in this area was handed down by the Court of Appeal in Canadian Ironworkers, No. 1 v. International Association of Ironworkers, No. 97.59 The Court ignored its previous decision in Doman's Transport. ${ }^{60}$ The Canadian Ironworkers, No. 1 Case concerned the status of "non-affiliation" clauses:

The Union reserves the right to render assistance to other labour organizations. Refusal on the part of union members to work with non-union workmen or workmen whose organization is not affiliated to the Building Trades Council, shall not be deemed a breach of this agreement

and a "sub-contractor's" clause by which the employer agreed not to contract out work falling within the jurisdiction of affiliated unions to contractors employing workmen not belonging to those unions.

All three judges declared that the clauses were not contrary to public policy at common law. Bull J.A. stated:61

In my view William Newell v. H. Barker and John W. Burce $e^{62}$ suports the validity of non-affiliation clauses. Rand J. said: ${ }^{33}$

It is now established beyond controversy that in competition between workmen and employers and between groups of workmen, concerted absention from work for the purpose of serving the interest of organized labour is justifiable conduct.

As to sub-contractors' clauses I can see no difference in principle, provided of course that breach of an existing contract is not inherent or calculated therein. Using lawful labour persuasion to induce a person to break an existing contract is a different matter entirely to using the same means to persuade any employer to not deal in the future with others whose labour practices may be considered unacceptable.

I therefore conclude, with the learned trial judge, that non-affiliation clauses or subcontractors' clauses, per se, are not objectionable at common law.

Davey C.J.B.C. agreed without comment. Nemetz J.A. (who dissented on

so For example, the Supreme Court of Canada in Int. Assoc. of Ironworkers, Local 97 v. Canadian Ironworkers, No. 1 [1972] 1 W.W.R. 518.

37 Doman's Transport v. Building and Truck Drivers' Union, Local 3163 C.L.L.C. [15,485] 784 (B.C.S.C.); Westland Carriers v. General Truck Drivers' Union Local 31, 69 C.L.L.C. [14,194] (B.C.S.C.). Mark Fishing Co. v. United Fishermen (1970) 16 D.L.R. (3d) 618 (B.C.S.C.), affirmed (1972) 24 D.L.R. (3d) 585 (B.C.C.A.), affirmed [1973] 3 W.W.R. 13 (S. Ct. Can.); Toronto Photo-Engravers' Union, No. 35 v. Toronto Star 71 C.L.L.C. [14,092] 14,500 (Ont. H.C.).

st 68 C.L.L.C. $[14,115] 495$ (1963) (B.C.C.A.).

s9 70 C.L.L.C. $[14,053] 14,336$, (1970) 73 W.W.R. 172 (B.C.C.A.).

60 See Nemetz J.A.'s remarks at 14,352 .

61 70 C.L.L.C. $[14,053] 14,336,14,347$; (1970) 73 W.W.R. 172 (B.C.C.A.).

62 [1950] S.C.R. 385 .

a. Id. at 397. 
another ground) cited Newell v. Barker to similar purpose. The latter case appears as dubious authority insofar as the validity of the "subcontractors" clauses was assumed, but never questioned, in the Supreme Court. The remarks of Rand $J$. were directed merely to the justification in conspiracy of a request to comply with the clause.

Nemetz J. A. described the contention that the clauses were invalid"the clauses are contrary to public policy [and/or] that public policy ought not to accept the use by labour unions of economic power to ensure that employees belong only to certain unions affiliated to each other in groups." 64 The learned judge commented that "the determination of such a sweeping proposition is for the legislature of this province." The conclusion indicates an appreciation of the dubious character of findings of public policy for the purposes of a doctrine founded upon nineteenth century notions of free enterprise in the area of modern labour relations.

Counsel submitted that the clauses were invalid as being contrary to the policy of the Trades-Union Act and/or the Labour Relations Act. "The claim of the affiliated unions that under their collective agreements they do not have to work with union employees employed by Century Steel and represented by the appellant union under certification by the labour relations board" was said to exemplify this problem. ${ }^{65}$ Nemetz $\mathrm{J}$. A. examined the operation of the labour relations legislation and concluded:66

In my view, there is no significant difference between a closed shop provision (which is specifically provided for under Section 8 of the Labour Relations Act, supra) and a non-affiliation clause. ...

... In my opinion, 19 craft unions engaged in the same industry, having a community of economic interest at a particular jobsite, by obtaining a non-affiliation clause, obtain no more than an industrial union would in obtaining a closed shop.

The learned judge declared the legality of the non-affiliation clause in the construction industry, and in so doing sought to identify and apply the public interest. The concern of Nemetz J.A. with the "community of economic interest" of employees at a particular job-site recognizes the problems of the distinct structure of the industry and affords a parallel to the exemption of the American construction industry from the application of section 8(e) of the National Labor Relations Act. The learned judge continued his inquiry into the demands of public policy in his examination of the sub-contractor's clause: 67

While I have no doubt that in this Province the general objective of seeking a nonaffiliation clause is lawful, I will restrict my views in regard to the legulity of the subcontractor's clause by saying that, so far as the evidence goes in this case, the objective was shown to be lawful because the purpose of seeking this clause was to preserve the work traditionally performed by jobsite ironworkers. (Such an objective was found to be lawful by Brennan J. expressing the majority opinion of the Supreme Court of the United States with which I would respectfully agree, in National Woodwork Manufacturers Association v. National Labour Relations Board (No. 110) 386 U.S. 612 at 614.) I do not find it necessary in the circumstances to consider what the situation might be where it was shown that the purpose was otherwise. I therefore conclude that in this case, it was shown that the objective of both the non-affiliation and subcontractor's clause was lawful.

The perception of Nemetz J.A. of the American situation is ad-

\footnotetext{
of Id. at 14,352 .

os Id. at 14,337 per Davey, J.A.

os Id. at $14,351 \cdot 14,352$.

id Id. at 14,353 .
} 
mirable. The American decision is, however, derived from the interpretation of section 8(e) of the National Labor Relations Act. That interpretation is founded upon the distinction between primary and secondary activity. The distinction is not accorded explicit recognition in any statute in British Columbia. Nemetz J.A. adopted the public policy declared by the United States Congress in the absence of any direction from the provincial legislature. The similarity of labour relations systems in the United States and Canada suggest that such an approach is acceptable until such time as the provincial legislature affords a clear declaration of public policy.

Counsel further maintained that the clauses were invalid as being contrary to the provisions of the Trades-Union Act and/or the Labour Relations Act. It was suggested, in particular, that the non-affiliation clause was invalid "because it contains the implicit right to stop work, a right which is illegal since it falls within the definition of strike in the Labour Relations Act and is specifically prohibited by 8. 46 [which banned strikes during the term of a collective agreement]." 68 Bull J.A. agreed "with the reasoning and conclusions of the learned trial judge." 69 The learned trial judge denied the invalidity of the clause because (i) it could be invoked lawfully prior to the commencement of a job as a method of indicating the labour organization's policy and (ii) it could be invoked lawfully after the commencement of the job provided that the grievance procedure was utilized-"then the employee may down his tools and leave the job."70

Upon examination of the sub-contractor's clause, Bull J.A. concluded: ${ }^{71}$

I can find nothing in the Labour Relations Act that makes it illegal for a subcontractors' clause to be agreed upon between a union and a contractor.

Davey C.J.B.C. concurred. The learned judge found that "neither clause is necessarily in conflict or inconsistent with either Act or its policy."72

In Canadian Pacific Railway v. Building and Truck Drivers Union, Local $213^{73}$ the collective agreement contained a "sub-contractors clause," a "non-affiliation clause," and an "unfair goods or persons clause." The latter provided that

It shall not be a violation of this Agreement or cause for dismissal of an employee to refuse to handle, receive, ship or transport any materials or equipment considered unfair by the Building Trades Council of B.C., or to work with or to receive from any persons or firms who are considered unfair by any of the said Building Trades Councils.

Verchere J. of the British Columbia Supreme Court stated: ${ }^{74}$

... the effect of the Ironworkers case has been to determine, insofar as I am concerned, the issue raised here regarding the illegality of the impugned clauses as objectionable, per se, at common law or as contrary to the provisions of the mentioned statutes.

es In Supreme Court of British Columbia: 67 C.L.L.C. $[14,054] 11,348,11,366$.

so 70 C.L.L.C. $[14,053] 14,336,14,347$ (B.C.C.A.).

70 In Supreme Court of British Columbia: 67 C.L.L.C. [14,054] 11,348, 11,367 per Rutton J. This conclusion suggests that such conduct lies outside the ambit of the "strike" prohibition during the term of a collective agreement.

770 C.L.L.C. $[14,053] 14,336,14,347$ (B.C.C.A.).

72 Id. at 14,337 .

3 [1971] 5 W.W.R. 1 (B.C.S.C.).

"Id. at 39. 
The learned judge determined that "the considerations regarding the legality of the sub-contractors' clause and the affiliation clause that were expressed in the Ironworkers case are applicable also to the unfair goods and persons clause."75 Verchere J. did not examine those considerations beyond a recitation of segments of the judgments of Bull J.A. and Davey C.J.B.C.

The decision of the Court of Appeal of British Columbia in the Ironworkers case was affirmed by the Supreme Court of Canada. ${ }^{76}$ Pigeon J., who delivered the judgment of the Court, refrained, however, from consideration of the legality of the clauses concerned.

\section{CONDUCT INDUCING ENTRY INTO A HOT-CARGO CLAUSE}

\section{A. Common Law}

The contrast between the common law and statutory regulation of hot-cargo clauses is revealed in the distinct regimes attached to conduct inducing entry thereto. The common law concern with the maintenance of contractual rights and freedom of contract both permits the securing of a hot-cargo clause and gives effect thereto.

Endeavours by a labour organization to induce the entry by an employer into a hot-cargo clause constitute interference with the creation of future contractual relationships. Tortious liability does not attach to such conduct.

Liability in conspiracy to injure was declared inapplicable in these circumstances by Rand J. in Newell v. Barker7 upon the authority of Crofter Harris Tweed v. Veitch. ${ }^{78}$

\section{B. Statute}

\section{United States}

Section 8(e) of the National Labor Relations Act declares entry into a hot-cargo clause by any labour organization or employer to be an unfair labor practice.

The NLRB has held that the absence of a request or attempt by the union to enforce a hot-cargo provision is no defence and that the act of entering into, signing, executing, or making a contract is sufficient to establish a violation. ${ }^{79}$

The legislation restricting the entry by unions and employers into hotcargo agreements is buttressed by the separate proscription of conduct directed towards the inducement of such agreements. Section $8(b)(4)(A)$ of the National Labor Relations Act, as amended in 1959, provides that it is an unfair labor practice for a union or its agents:

... (i) to engage in, or to induce or encourage any individual employed by any person engaged in commerce or in an industry affecting commerce to engage in, a strike or a refusal in the course of his employment to handle goods or perform services. ...

or (ii) to threaten, coerce or restrain any person engaged in commerce or in an industry affecting commerce, where in either case an object thereof is:

(A) forcing or requiring any employer... to enter into any agreement which is prohibited by section 8(e).

\footnotetext{
is Id. at 36.

78 [1972] I W.W.R. 518.

7 [1950] S.C.R. 385, 397

in [1942] A.C. 435.

${ }^{79}$ American Feed Co. 133 NLRB No. 23 (1961), 48 L.R.R.M. 1622.
} 
The distinctive aspect of section $8(\mathrm{~b})(4)(\mathrm{A})$ is that it lacks the proviso attached to section $8(\mathrm{~b})(4)(B)$ which limits the prohibition contained therein to secondary activity. It is thus that primary, as well as secondary conduct, is barred under section $8(\mathrm{~b})(4)(\mathrm{A})$.

The application of section $8(\mathrm{~b})(4)(\mathrm{A})$ to the construction and apparel industries was a matter of dispute. The NLRB had held that economic pressure to obtain an agreement unlawful under section 8(e) apart from the construction industry proviso, is a violation of section $8(\mathrm{~b})(4)(\mathrm{A})$ even in the construction industry. ${ }^{80}$ It has since abandoned this position ${ }^{81}$ in deference to such authority as Construction Laborers Local 383 (Colson \& Stevens Const. Co.) v. NLRB ${ }^{82}$ decided by the U.S. Court of Appeals at San Francisco, which held that. ${ }^{83}$

... picketing to secure an agreement to cease doing business with certain persons is not made wrongful by this section where that agreement is within the construction proviso of section $8(\mathrm{e})$.

\section{Alberta, British Columbia, New Brunswick and Newfoundland}

In Doman's Transport v. Building and Truck Drivers' Union, Local $31^{84}$ Aikins J. remarked:85

In so far as section 2 of Article II can be regarded as an agreement not to do business with the plaintiffs, or any firm in a like situation, the building supply firms which signed the building supply agreement must have been persuaded to so agree before signing. It was not argued for the plaintiffs that the union acted unlawfully under section 3(2) [see now 8. 1(1) and 8. 85, Labour Code of B.C.] of the Trade-Unions Act in persuading Deeks-McBride Ltd., or any other firm, to agree not to do business with any carrier whose employees were not represented by a local of the Teamsters union if another carrier whose employees were so represented was available for the work required.

The learned judge refrained from further consideration of the problem. The provincial restraint upon persuasion would seem to perform an analogous function to section $8(\mathrm{~b})(4)(\mathrm{A})$ in precluding the inducement of entry into hot-cargo agreements. In Canadian Ironworkers Union No. 1 v. International Assoc. of Ironworkers, Local 97, Davey C.J.B.C. determined:86

The evidence I have discussed makes it clear that at both meetings the Council endeavoured to persuade the contractors and subcontractors not to employ workmen belonging to non-affiliated unions, and specifically those belonging to the appellant (the effect of a non-affiliation clause). By seeking to have the employers not employ members belonging to the appellant, it successfully persuaded the employers not to do business with the members' duly certified bargaining agent, the appellant, who represented them. To the extent that the Council persuaded the construction association not to sublet work to contractors employing workmen who were members of the appellant, i.e., Century Steel, among others, (the effect of a non-subcontracting clause) it was a successful attempt to persuade the contractors to refuse to do business with Century Steel, and because Century Steel was represented at the first meeting, it was an attempt to induce Century Steel not to do business with the appellant or to employ its members.

The provincial limitations upon the inducement of a hot-cargo clause are, however, subject to the permission extended by the legislation to

\footnotetext{
no Construction Laborers' Local 383137 NLRB 1650 (1962).

" Building Const. Trades Council (Centlivre Village Apts.) 148 NLRB 854 (1964).

32 323 F.2d. 422 (CA-9; 1963); 48 L.C. [18,515] 29,933.

1. Id. at 29,936 .

is 63 C.L.L.C. $[15,485] 784$ (B.C.S.C.).

ss Id. at 788 .

n6 70 C.L.L.C. $[14,053] 14,336$ at 14,339 (B.C.C.A.).
} 
persuasion conducted at specified locations e.g. at the lawfully striking employees place of employment. The legislation does not prevent the exercise of economic pressure directed towards the obtaining of a hot-cargo clause in the usual, and lawful, manner employed in the settlement of a collective agreement.

\section{OPERATION OF HOT-CARGO CLAUSE}

\section{A. Restraints imposed during term of collective agreement}

The restrictions to which union activity is subjected during the term of a collective agreement are voluntarily established by the parties in the United States and Saskatchewan. The customary restraints imposed by a collective agreement upon economic action in the form of a "no-strike" clause might, accordingly, be confined so as to permit the operation of a hot-cargo clause.

Legislation in the other Canadian jurisdictions prohibits industrial action during the continuance of a collective agreement irrespective of the terms agreed between the parties. The enjoinder of industrial action is accomplished by the proscription of "strikes" 87 during the operation of a collective agreement. The evasion of such restraint by a hot-cargo clause depends upon a determination that work that the employer agrees that the employees need not handle is not "work" within the meaning of the definition of a strike. ${ }^{88}$

The constituents of "work" have been examined in several cases, including Kelly, Douglas \& Co. v. Bakery and Confectionery Workers', Local 468.89 The suggestion, drawn from the remarks made by Collins J. in that case, is that a strike may consist in the refusal by employees to do their customary work. The nature of "customary work" may be elucidated by the remarks of Ferris C.J.S.C. in Re Marine Workers and Boilermakers Industrial Union, Local No. 1 and Labour Relations Board of British Columbia,90 to which Collins J. made reference. The Chief Justice commented.91

... in interpreting "strike," it would seem to me the words "including cessation of work, refusal to work, or refusal to continue to work" must refer to such work as is contemplated by the Act, and this necessarily includes the collective agreement...

In John Inglis Co. v. United Steelworkers, Local $2900^{92}$ the effect of a clause in a collective agreement that excluded certain work from the obligations of the employees was considered. It appears that negotiations were under way between the employer and the union for the renewal of a collective agreement. During the currency of the negotiations, the employees in concert refused to work overtime. E. N.

87 Note: Labour Relations Act (Manitoba) S.M. 1972, c. 75. In Manitoba section 77(2) prohibito a strike while a collective agreement is in force. Section 12(1) exempts a "refusal to perform work which would directly facilitate the operations" of a lawfully struck employer from disciplinary action or from constituting a breach of a collective agreement or contract of employment. Section 121) does not prevent the issuance of an injunction for the conduct of a partial boycott in violation of section 77(2).

ss See discussion of definition of "strike" at page 5 . The definition of strike in $8.1(v)$ Labour Relations Act (Manitoba) S.M. 1972 c. 75 may not permit of contractual evarion by means of a hol-cargo clause. The definition includes:

... a refusal to continue the standard cycle or normal pattem of operation in a place of employment ...

69 (1965) 48 D.L.R. 520 (B.C.S.C.).

$\infty$ (1951) 4 W.W.R. 529 (B.C.S.C.).

91 Id. at 533.

9253 C.L.L.C. [17,049] 1438 (O.L.R.B.), (1952) C.L.S. $76-373$. 


\section{Davis for the majority of the Ontario Labour Relations Board remarked: ${ }^{93}$}

In our opinion, the obligation of employees to work overtime must be dependent in every case upon the contract of employment existing between the employee and the employer. 'l'his involves not only the collective agreement but all the unwritten conditions of employment, published policies, customs and practises existing in a given situation....

Did the legislature intend to make illegal a refusal to work where the original request of the employer for overtime work is made in the face of an agreement between the parties prohibiting overtime or where the request is made without fulfilling agreed upon conditions precedent? We do not think it could have so intended, but are of the opinion that the refusal can only become of significance where it has been preceded by a request of a type which the employer is entitled to make.

A hot-cargo clause stipulates circumstances in which an employer may not require employees to undertake certain tasks, for example, the handling of goods produced by an "unfair" employer. The comments of E. N. Davis intimate that a partial boycott by employees in a situation specified in such a clause would not constitute a strike. The conclusions of E. N. Davis were repeated by J. Finkelman in Harding Carpets v. Canadian Textile Council, Local No. 501.94

A declaration of the legality of a partial boycott undertaken pursuant to a hot-cargo clause has, however, yet to be offered by a Canadian court. ${ }^{95}$ The problem remains to be adjudicated in circumstances not permeated by an extraneous unlawful element. In Canadian Ironworkers Union No. 1 v. International Association of Ironworkers, Local $97^{96}$ in the Court of Appeal of British Columbia the illegality of the strike was conceded.97

Arising from the same circumstances is Canadian Pacific Railway et al v. Building and Truck Drivers Union, Local 213.98 The corporate plaintiff was a carrier. Much of its business consisted of the carriage of materials from suppliers to various construction sites. Its employees were members of the plaintiff union, the Canadian Brotherhood of Railway Trainmen, which was not a local union in good standing with any of the defendant international unions and did not, therefore, qualify for membership of any of the defendant councils. As a result of insistence by the defendant unions of strict observance by the employers of "sub-

23 Id. at 376 . Italics added.

94 56 C.L.L.C. $[18,031] 1564$ (O.L.R.B.).

A contrary suggestion may be culled from MacMillan Bloedel (Alberni) Ltd. v. I.W.A., Local 1.85, 70 C.L.L.C. [14,023] 14,220 (B.C.C.A.). Taggart J.A., delivering the judgment of the Court of Appeal of British Columbia, commented at 14,224 :

$\ldots$ the contractual obligations of the parties . . . is not a determining factor in construing the meaning to be given to "work" where it is used in the definitions of strike and lockout in the Mediation Commission Act. On the contrary, it is my view that one must first have regard to one of the primary purposes of the legislation which is, all are agreed, to insure industrial peace during the currency of a collective agreement.

The learned judge refuted the suggestion of employer's counsel that a provision specifically not "guaranteeing to any employee any number of hours of work per day or per week" might be invoked to evade the restrictions upon a "lockout" during the term of a collective agreement. The application of Taggart, J.A.'s remarks to hotcargo clauses are, however, subject to his reservation that the disputed provision "may, of course, be used by the employer for a proper purpose" contemplated at the time of agreement, e.g." "where it is necessary for him to cut back production because of a lack of orders." The invocation of a hot-cargo clause to preclude the handling of atruck goods, would appear to be for a "proper purpose" contemplated at the time of the agreement.

as Albeit such a conclusion seems implicit in the reasoning of Rutton $\mathrm{J}$. in the British Columbin Supreme Court in Canadian Ironworkers No. $1 \mathrm{v}$. Int. Assoc. of Ironworkers, Local 97. 67 C.L.L.C. $[14,056] 11,368,11,367$. The learned judge's reasoning was approved by Bull, J.A. in the Court of Appeal: 70 C.L.L.C. [14,053] 14,336, $14,347$.

96 (1970) 73 W.W.R. 172; 70 C.L.L.C. $[14,053] 14,336$ (B.C.C.A.).

Id. at 14,224 .

[1971] 5 W.W.R. I (B.C.S.C.). 
contractors' clauses," "non-affiliation clauses" and "unfair goods clauses" plaintiffs suffered substantial damage in that vehicles of the corporate plaintiff were denied access to job sites to which they were carrying materials and suffered other kinds of interference which, on occasions, forced the corporate plaintiff to withdraw from valuable contracts into which it had entered for the carriage of goods. The plaintiff union also suffered consequential damage.

Verchere J. considered that the conduct of the defendant unions consisted of "the often-repeated threat to tie up the job. [T] was thereby threatened was, in my view, in every sense a "strike" as defined in s. 2 of The Mediation Act, 1968 (B.C.), c. 26. Accordingly, it seems to me and I hold, that what was threatened was an illegal strike."99 The learned judge did not consider the relationship of the disputed clauses to the definition of strike. Such was made unnecessary as the defendant unions failed to confine the threats of industrial action and the boycotts undertaken to that provided for in the clauses. In several instances a strike or threat thereof was induced or made by members of several unions, only one of which was party to such a clause in its collective agreement.

\section{B. The Inducement of a Partial Labour Boycott}

\section{Common Law}

Liability in interference with existing contractual relations is conventionally suggested to be founded upon a breach of contract. The conduct of a labour boycott may entail a breach of a contract of employment. A hot-cargo clause in a collective agreement may negate the existence of such breach.

Dryer J. in the Supreme Court of British Columbia commented in Nelsons Laundries Ltd. v. Manning:100

In the absence of some evidence to indicate a contrary stipulation I must find that the terms of (the contract of service between the plaintiff and the defendant) are those terms of the collective agreement which deal with the rights and obligations which are to subsist between the employer on one part and the employee on the other.

A hot-cargo clause may thus be drafted so as to preclude a breach of contract of employment in the circumstances of a partial boycott. Such a development would deny liability in interference with existing contractual relations in the absence of the breach of a commercial contract. Thus in Edinburgh Developments and Cascade Builders v. $C$. Vanderlaan and $E$. Sentes ${ }^{101}$ Prowse J. in the Appellate Division of the Supreme Court of Alberta commented:102

... as many Union contracts provide that members are entitled to respect picket lines of others, I would have some difficulty characterizing the acts of members of such unions in respecting a picket line as a breach of their contract of employment when they had bargained for and obtained the right not to be required to cross a picket line.

In Mark Fishing v. United Fishermen and Allied Workers ${ }^{103}$ Rae J. of the Supreme Court of British Columbia denied the ability of a hot-cargo

\footnotetext{
99 Id. at 48.

100 (1965) 51 D.L.R. (2d) 537 at 544 (B.C.S.C.).

su1 [1974] 3 W.W.R. 481 (Alta. C.A.).

102 Id. at 496 .

${ }^{303}$ (1970) 16 D.L.R. (3d) 618 (B.C.S.C.).
} 
clause to negate a breach of contract of employment. ${ }^{104}$ The learned judge appeared to consider the circumstances analogous to those of Torquay Hotel v. Cousins ${ }^{105}$ where a force majeur clause appeared in a commercial contract. It is respectfully submitted that the learned judge was in error. In Torquay the exception clause was intended to protect the parties to the commercial contract from liability for non-compliance with the other terms of the contract in circumstances beyond "their immediate control, including ... labour disputes." It was not intended to protect the labour organization. In Mark Fishing the clause explicitly exempted a refusal to handle by the members of the union from constituting a violation of the collective agreement.

Direct persuasion of an employer to breach a commercial contract or interfere with its performance may be justified by a hot-cargo clause. ${ }^{106}$ In Posluns v. Toronto Stock Exchange, ${ }^{107}$ Gale J. considered that where a person acts in accordance with a right conferred upon him by contract he may be justified in procuring the breach of another's contract. ${ }^{108}$ The leading cases concerning labour dispute circumstances, Read v. Friendly Society of Stonemakers ${ }^{109}$ and Smithies v. National Association of Operative Plasterers, ${ }^{110}$ may not be readily reconciled and were decided in the early part of the century. In the latter case it stated:111

There are circumstances in which $A$ is entitled to induce $B$ to break a contract entered into by $B$ with $C$. Thus for instance, if the contract between $B$ and $C$ is one which could not be made consistently with his preceding contractual obligations toward A, A may not only induce him to break it, but may invoke the assistance of a Court of Justice to make him break it.

Recognition of such justification may preclude the unfortunate situation where a hot-cargo clause might be enforced by a partial boycott without attracting tortious liability [indirect interference with existing contractual relations], while the communication of such intent to an employer without such boycott would found liability [in direct interference with commercial contract].

Newell v. Barker and Bruce 112 affords the authority of the Supreme Court of Canada to the proposition that the enforcement of a hot-cargo clause-in that instance, a sub-contractor's clause-may justify a conspiracy to injure. ${ }^{113}$

It is now established beyond controversy that in competition between workmen and employers and between groups of workmen, concerted abstention from work for the purpose of serving the interest of organized labour is justifiable conduct.

\section{Statute}

(a) United States

The prohibition embodied in section $8(\mathrm{~b})(4)(\mathrm{B})$ of the National Labor Relations Act extends only to secondary conduct. The criterion for deter-

104 Id. at 638.

In the Court of Appeal, McLean and Robertson J. JA. maintained liability in direct interference with existing contractual relations and thus obviated any substantial concern with the problem: (1972) 24 D.L.R. (3d) 58.5. 609 and 621 .

ics [1969] 2 W.L.R. 289 (C.A.).

ins See discussion I. M. Christie, The Liability of Strikers in the Law of Tort. (Queen's Ontario, 1967) pp. $133-139$.

107 (1964) 46 D.L.R. (2d) 210 (Ont. H.C.).

sax Id. at 271.

100 [1902] 2 K.B. 732 (CA.).

110 [1909] 1 K.B. 310 (C.A.).

I1I Id. at 337 per Buckley L.J.

112 [1950] S.C.R. 385.

iss Id. at 397 per Rand J. 
mining whether conduct seeking compliance with a hot-cargo clause constitutes primary or secondary behaviour was considered by Brennan J. in National Woodwork Manufacturers' Association v. NLRB. ${ }^{114}$ The learned judge concluded that the "touchstone is whether maintenance [of the agreement] is addressed to the labor relations of the contracting employer vis-a-vis his own employees." 115 In the instant case the Court determined: ${ }^{116}$

The Union's maintenance of the provision was not a violation of section 8(b)(4)(B). The union refused to hang prefabricated doors whether or not they bore a union label, and even refused to install prefabricated doors manufactured off the jobsite by members of the Union. This and other substantial evidence supported the finding that the conduct of the Union on the Frouge jobsite related solely to preservation of the traditional tasks of the jobsite carpenters....

A hot-cargo clause does not preclude the inducement of a partial boycott from constituting a violation of section $8(b)(4)(B)$. The contention was fully considered in Local 1976, United Brotherhood of Carpenters v. NLRB (Sand Door) 117 in the Supreme Court. ${ }^{118}$

The argument that a hot cargo clause is a defense to a charge of a violation of section $8($ b) (4)(A) [now section $8(\mathrm{~b})(4)(B)$ ] may be stated thus: the employer has by contract voluntarily agreed that his employees shall not handle the goods. Because of this consent, even if it is sought to be withdrawn at the time of an actual work stoppage and boycott, it cannot be said, in the light of the statutory purpose, either that there is a 'strike or a concerted refusal' on the part of the employees, or that there is a "forcing or requiring" of the employer. Only if consideration is confined to the circumstances immediately surrounding the boycott, in disregard of the broader history of the labor relations of the parties, is it possible to say that the employer is coerced into engaging in the boycott. If the purpose of the statute is to protect neutrals from certain union pressures to involve them involuntarily in the labor disputes of others, protection shoud not extend to an employer who has agreed to a hot cargo provision, for such an employer is not in fact involuntarily involved in the dispute....

The Union does no more than inform the employees of their contractual rights and urge them to take the only action effective to enforce them.

\section{The Court determined:119}

It seems most probable that the freedom of choice for the employer contemplated by section $8(b)(4)(A)$ is a freedom of choice at the time the question whether to boycott or not arises in a concrete situation calling for the exercise of judgment on a particular matter of labor and business policy....

The employees' action may be described as a 'strike' or 'concerted refusal,' and there is a 'forcing or requiring' of the employer, even though there is a hot cargo provision. The realities of coercion are not altered simply because it is said that the employer is forced to carry out a prior engagement rather than forced now to cease doing business with another....

Thus inducements of employees that are prohibited under section $8(b)(4)(A)$ in the absence of a hot cargo provision are likewise prohibited when there is such a provision.

Direct appeals to employers to observe a hot-cargo agreement do not, however, establish a violation of section $8(b)(4)(B)$. Frankfurter J. remarked in the Sand Door case: ${ }^{120}$

Of course if any employer does intend to observe the contract, and does truly sanc-

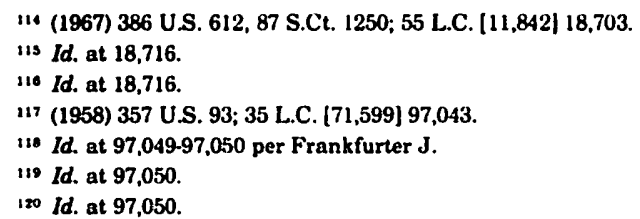


tion and support the boycott, there is no violation of section $8(b)(4)(A)$. A voluntary employer boycott does not become prohibited activity simply because a hot cargo clause exists.

The garment industry exemption for the secondary boycott ban extends to section $8(b)(4)(B)$. Economic coercion directed to the enforcement of a hot-cargo clause in the industry is not a violation of the provision.

The significance of the Sand Door decision today is confined to the construction industry. It was determined in Northeastern Indiana Bld. \& Con. Trades Council (Centlivre Village Apartments) 121

$\ldots$ under Section 8(b)(4)(B) lawful 'hot cargo' clauses may be enforced only through lawsuits, and not through economic action. ${ }^{122}$ If Respondents had had such a clause with Centlivre and pursuant thereto had, by picketing, sought to have Centlivre cease doing business with $\mathrm{K} \& \mathrm{~K}$, the picketing would have violated $8(\mathrm{~b})(4)(\mathrm{B}) .^{123}$

(b) Alberta, British Columbia, New Brunswick and Newfoundland The Provincial legislation proscribes persuasion of anyone not to:

(a) enter an employer's place of business, operations, or employment; or

(b) deal in or handle the product of any person; or

(c) do business with any person

except at the employer's place of business, operations or employement where there is a lawful strike or lockout.

The enforcement of a hot-cargo clause may be considered in terms of the presence of persuasion at the time of its enforcement. Under Sand Door direct appeals to employers to observe a hot-cargo clause were not unlawful because "coercion" might be absent. Similar circumstances under the provincial legislation would appear to suggest the presence of persuasion. A communication to an employer pointing out the terms of a hot-cargo clause could not be interpreted as not having been intended to have sought a proscribed effect.124 Instructions to employees to participate in a partial boycott within the ambit of a hot-cargo clause clearly constitute unlawful persuasion. ${ }^{125}$ The delineated circumstances in which persuasion is permitted do not provide for contractual exemption.

'121 148 NLRB 854 (1964).

122 Orange Belt District Council of Painters, No. 48 v. NLRB, 117 U.S. App. D.C. 233, 328 F.2d. 534,537 (1964).

$12: 148$ NLRB, 854, 857 (1964).

124 See: Sonoco v. Pulp and Paper Mill Workers, Local 433 (1970) 73 W.W.R. 458, 462 (B.C.C.A.).

c.f.: In Doman's Transport v. Building. Fuel Truck Drivers' Union, (1963) 40 D.L.R. 492, 63 C.L.L.C. [15,485]

784,788 (B.C.S.C.). Aikins J. concluded:

I am therefore inclined to the view that the real aubstance of what the union has done and threatens to do is to demand that building supply firms which have signed the building supply agreement with the union do what they agreed to do, that is give preference to carriers whose employees are represented by a local of the Teamsters union which, incidentally, may require that such firms do not do any business with the plaintiffs. ...

... I have the very greatest doubt as to whether for the defendant union to point out to a building supply firm that the agreement requires that it give preference to carriers whose employers are represented by a local of the Teamsters union and not engage a carrier whose employees are not so represented and demand that the building supply firm honour its agreement, can be considered to be an endeavour to persuade the building supply firm not to do business with the latter carrier and accordingly be held to be un. lawful under section $3(2)$ of the Trade.Unions Act.

Also see: C.P.R. v. Building and Truck Drivers Union, Local 213 [1971] 5 W.W.R. 1, 46 (B.C.S.C.).

ts Mark Fishing v. United Fisherman and Allied Workers, (1970) 16 D.L.R. (3d) 618, 634 (B.C.S.C.), affirmed (1972) 24 D.L.R. (3d) 585, 604, 618 (B.C.C.A.) affinned [1973] 3 W.W.R. 13 (S. Ct. Can.).

But compare: Westland Carriers Ltd. and General Truck Driucrs Union, Local 31. 69 C.L.L.C. [14,194] 783 (B.C.S.C.). The plaintiff was a trucking company engaged in the Business of transportaing petroleum products from oil refineries to prospective customers. Collective agreements were in effect between the plaintiffs and the defendant unions. A lawful strike was called at several of the refineries and picket lines around the refineries set up. A term of the collective agreements recugnized the right of the plaintiff s empluyees to refuse to cross a picket line set up lawfully by another union. To circumvent the provision the supervisury per. sonnel of the plaintiff in breach of the collective agreement drove the trucks through the picket lines and turned them over to union employees. The unions objected to the procedure and advised the plantiff that its members would not handle the trucks so operated.

The plaintiff sought un injunction against the unions on the ground that the persuasion by union officials of 
In Mark Fishing v. United Fishermen and Allied Workers ${ }^{126}$ Robertson J.A. commented:

Another matter that I should refer to at this stage is the clause [hot-cargol in the collective agreement between certain shoreworkers and the plants...

In my opinion this clause is not an answer... to a claim for damages under the Trade-Unions Act.The question is not whether the union would be in violation of its agreement with the Co-op if members of the union were to refuse to handle the products of certain people; rather it is whether the appellants did the acts complained of to the injury of the respondents.

The sentiments of Robertson J.A. were echoed very recently by Fulton $\mathrm{J}$. in the British Columbia Supreme Court in Pacific Trollers Assn. v. United Fishermen and Allied Workers. ${ }^{127}$

The union, in my view, cannot be heard to say that it or its officers are justifed in their conduct of requiring the shoreworkers not to handle the fish or boats in question on the basis that the collective agreement covering those shoreworkers provides that such refusal is not a breach of that agreement, when the conduct by which those officials bring about that result is itself prohibited by law. It is the conduct of the union officials in persuading or endeavouring to persuade the shoreworkers and their employers not to 'deal in or handle the products' of the plaintiffs and not to 'do business with' the plaintiffs, and not the conduct of the shoreworkers or the companies with respect to the collective agreements, which is in question here. That conduct of the union officials is expressly prohibited by the provisions of The Trade-Unions Act in s. 3(2). [Now s. 1(1), 85 B.C. Labour Code] ...

It is not open to them, by writing into the provisions of a collective agreement a provision of the nature in question here [a hot cargo clause], and unilaterally declaring that the disagreement between themselves and the plaintiffs is a "dispute with labour" within the meaning of that article, to put their subsequent conduct outside the operation of the statute which is designed to prevent just that conduct, and claim justification accordingly.

\section{CONCLUSION}

The hot-cargo clause endeavours to preserve the right of employees to engage in a partial labour boycott in specified circumstances during the term of a collective agreement.

The "hot-cargo" clause has been declared void in the United States insofar as it seeks to protect the conduct of secondary activity i.e. conduct considered to broaden the ambit of a labour dispute beyond its proper boundaries. Clauses directed to the preservation of the contracting employees' work or the protection of a refusal to cross a primary picket line are not considered secondary. Excepted from the declaration of invalidity are clauses agreed in the apparel and construction industries. Entry into a void clause constitutes an unfair labour practice and conduct, primary or secondary, inducing such entry is proscribed. Enforcement of a "secondary" provision is proscribed except in the apparel and construction industries. Enforcement in the latter industry is, however, only permissible insofar as it constitutes the securing of "voluntary compliance." The rationale of the United States regulation of the hot-cargo clause consists in the preservation of the freedom to so contract except

\footnotetext{
the plaintiffs employees not to handle the trucks was a breach of section 3(2) of the Trade Unions Act of British Columbia.

The application was dismissed by Hinkson $J$. The learned judge determined that an employer who was in breach of the terms of a collective agreement, which in turn led its employees to adopt a certain position could not then invoke those provisions to obtain an interlocutory injunction since the person seeking it "must come with clean hands in the equitable sense."

128 (1972) 24 D.L.R. (3d) 585, 621 (B.C.C.A.). Italics added.

${ }^{127}$ [1974] 4 W.W.R. 561, 575-576 (B.C.S.C.).
} 
where the public interest in confining the ambit of a dispute to its immediate participants is considered pre-eminent i.e. in all but the apparel and construction industries.

In Alberta, British Columbia, New Brunswick and Newfoundland the curious position has been established that the hot-cargo clause is not invalid, neither is conduct receiving entry thereto necessarily unlawful, but conduct securing compliance therewith is illegal. The legislature of the four provinces have articulated the permissible ambit of a labour dispute. The declaration of policy does not permit "contracting-out" therefrom. The legislation maintains the Canadian tradition rejecting the freedom of labour organizations to contract as to the extent to which they shall refrain from industrial action during the term of a collective agreement.

At common law endeavours by a labour organization to induce the entry by an employer into a hot-cargo clause constitute interference with future contractual relationships. Liability does not attach to such conduct. Despite a reluctance to confer judicial recognition the enforcement of such a clause does not invoke liability in interference with existing contractual relationships since the performance of the obligations under the collective agreement cannot be said to have been interfered with. If the performance of a commercial contract is interfered with by such enforcement the hot-cargo clause may afford justification and negate liability. Tortious liability has focused upon the protection of contractual rights as are secured by the free deployment of economic power. The recognition and efficacy afforded the hot-cargo clause at common law merely maintains this aspect of the policy of free enterprise. The public policy barring restraints of trade has not been utilized to vitiate the clause.

The Woods Report ${ }^{128}$ recommended extensive changes in the law of picketing in Canada. In particular it was suggested that it not be unlawful for employees to refuse to cross a primary picket line or a picket line assembled outside an "ally" of a primary employer. It was then commented:129

... we see no need for what have come to be called 'hot-cargo' agreements. In order to preserve the integrity of the codified law, we recommend that the parties be prohibited from contracting out of the new law in this or any other manner.

Only in British Columbia has the legislature responded to the recommendation. In 1972 , Bill 88 was introduced by the Social Credit Government. Section 1(b) provided:

... any provision of an agreement that requires or permits, or has the effect of requiring or permitting, a person to persuade or endeavour to persuade anyone not to do ... [business with any person] is null and void and of no effect.

The Bill was withdrawn.

The hallowed concept of "freedom of contract" enables the accommodation of the interests of the contracting parties. Public and other private interests are left out of account. In particular, the public interest in minimizing industrial unrest is ill-served by private agreements permitting the proliferation of the ambit of a dispute. In the United States this evaluation has provoked the confinement of the efficacy of the hot-

22s Canadian Industrial Relations. The report of the Task Force on Labour Relations (Canada, 1968).

129 Para. 629. 
cargo clause to primary activity. Such activity may, however, be carried out pursuant to a hot-cargo clause during the collective agreement. In Alberta, British Columbia, New Brunswick and Newfoundland the latter role is denied the hot-cargo clause. The rationale of such denial is the traditional Canadian policy barring industrial action, irrespective of agreed restraint, during the term of a collective agreement. It is suggested that such policy does not entail the proscription of the partial labour boycott when its exercise is provided for in the collective agreement, and such exercise does not violate the bounds of activity permitted when "lawfully on strike."130 The legislation might extend permission to activity undertaken pursuant to a hot-cargo clause and within such bounds. It may be that the circumstances or a particular industry demand greater scope for the hot-cargo clause e.g. the construction industry. Such exception may be articulated by the legislature, as in the United States, or by a tribunal such as a Labour Relations Board.

In the remaining Canadian jurisdictions the hot-cargo clause affords a device to repair and further imbalances in bargaining power produced by the workings of the industrial torts. The efficacy of the clause in promoting secondary activity would seem to encourage such imbalances. To suggest the proper role for the clause in those jurisdictions is, however, pointless until such time as the various legislature scrape together the courage to enunciate a policy regarding the proper ambit of industrial action undertaken pursuant to a labour dispute. The hot-cargo clause can be regulated so as to afford valuable flexibility in a labour relations system-but only if that system effects and seeks to maintain rational configurations of bargaining power.

130 See s. 156 Alberta Labour Act S.A. 1973 c. 33; 8. 1(1), 85 Labour Code British Columbia S.B.C. 1973 c. $122 ;$ s. 105 Industrial Relations Act S.N.B. 1971 c. 9; s. 43A Labour Relations Act R.S.N. 1952 c. 258. 